\title{
PENGARUH GAYA BELAJAR DAN MOTIVASI BELAJAR MAHASISWA TERHADAP KEMAMPUAN BELAJAR ILMU ALAMIAH DASAR
}

\author{
ADI PERMANA \\ adipermana84@yahoo.co.id \\ Program Studi Pendidikan Bahasa Indonesia \\ Fakultas Bahasa dan Seni Universitas Indraprasta PGRI \\ Jl. Nangka 58 Tanjung Barat, Jakarta Selatan, Indonesia
}

\begin{abstract}
Abstrak. Tujuan penelitian ini adalah untuk mengetahui pengaruh gaya belajar terhadap kemampuan belajar ilmu alamiah dasar, mengetahui pengaruh motivasi belajar terhadap kemampuan belajar ilmu alamiah dasar dan mengetahui pengaruh/ interaksi gaya belajar dan motivasi belajar terhadap kemampuan belajar ilmu alamiah dasar. Penelitian ini dilakukan pada mahasiswa universitas Indraprasta program studi pendidikan bahasa Indonesia. Sampel terdiri atas 84 mahasiswa yang dibagi ke dalam enam kelas penelitian yang masing terdiri atas 14 mahasiswa. Sampel diambil dengan teknik random sampling. Metode yang digunakan dalam penelitian ini adalah metode survey Expose Facto dengan analisis Anova dua arah dengan desain faktorial 2x3. Hasil penelitian ini membuktikan terdapat pengaruh gaya belajar terhadap kemampuan belajar ilmu alamiah dasar dibuktikan sig untuk gaya belajar $0,00<0,05$. Terdapat pengaruh motivasi belajar terhadap kemampuan belajar ilmu alamiah dasar dibuktikan sig untuk motivasi belajar $0,037<0,05$. Terdapat pengaruh interaksi gaya belajar dan minat belajar siswa terhadap kemampuan belajar ilmu alamiah. Hal ini ditandai dengan nilai sig interaksi gaya belajar dan motivasi belajar siswa $0,002<0,05$ dan didukung dengan perolehan nilai $\mathrm{F}$ hitung diamana $F_{\text {hitung }} 6,87>F_{\text {tabel }} 3,96$.
\end{abstract}

Kata Kunci : Gaya Belajar, Motivasi, Kemampuan Belajar IAD, Pengaruh.

\begin{abstract}
The purpose of this study was to determine the effect on the ability of learning styles to learn basic natural science, determine the effect on the ability of learning motivation to learn basic natural science and know the effect of the interaction of learning styles and motivation toward learning ability of natural science base. This research was conducted on university students Indraprasta Indonesian education courses. The sample consisted of 84 students who were divided into six classes, each study consisted of 14 students. Samples were taken by random sampling technique. The method used in this research is survey method Expose Facto with two-way ANOVA analysis with $2 \times 3$ factorial design. The results of this research prove there is a learning style influence on the ability to learn basic natural science to the learning style proved sig $0.00<0.05$. There is a learning motivation influence on the ability to learn basic natural science to study motivation demonstrated sig $0.037<0.05$. There is an interaction effect of learning styles and student interest in the ability to learn natural science. It characterized with sig interaction style of learning and student motivation $0.002<0.05$ and supported by the acquisition of $\mathrm{F}$ count when $\mathrm{F}_{\text {count }} 6.87>3.96 \mathrm{~F}_{\text {table. }}$.
\end{abstract}

Keywords: Learning Styles, Motivation, Learning Ability IAD, Influence.

\section{PENDAHULUAN}

Belajar merupakan aktivitas manusia yang penting dan tidak dapat dipisahkan dari kehidupan manusia, bahkan sejak mereka lahir sampai akhir hayat. Pernyataan tersebut menjadi ungkapan bahwa manusia tidak dapat lepas dari proses belajar itu sendiri sampai 
kapanpun dan dimanapun manusia itu berada dan belajar juga menjadi kebutuhan yang terus meningkat sesuai dengan perkembangan Ilmu Pengetahuan. Perkembangan Ilmu Pengetahuan Alam (IPA) telah maju dengan pesatnya karena selalu berkaitan erat dengan perkembangan teknologi yang memberikan wahana yang memungkinkan perkembangan tersebut. Perkembangan yang pesat telah menggugah para pendidik untuk dapat merancang dan melaksanakan pendidikan yang lebih terarah yang dapat menunjang kegiatan sehari-hari dalam masyarakat. Kemampuan dalam merancang dan melaksanakan pendidikan yang terarah merupakan beban yang harus ditanggung oleh para pendidik dalam hal ini dosen untuk dapat memberikan materi, arahan, bimbingan dan motivasi kepada mahasiswa agar dapat memiliki kemampuan yang diharapkan.

Perkembangan ilmu alamiah tidak hanya ditunjukkan oleh kumpulan fakta saja (produk ilmiah) tetapi juga oleh timbulnya metode ilmiah dan sikap ilmiah. Jadi metode ilmiah itu merupakan bagian dari ilmu alam. Selama proses belajar mengajar sejalan dengan hakikat ilmu alamiah maka pemahaman siswa terhadap ilmu alamiah menjadi lebih bermakna. Namun kenyataan sehari-harinya, dalam suatu kelas ketika sesi Kegiatan Belajar-Mengajar (KBM) berlangsung, nampak beberapa mahasiswa belum mampu mengikuti kegiatan belajar dengan baik. Jika masalah ini dibiarkan berlanjut, generasi penerus bangsa akan sulit bersaing dengan generasi bangsa-bangsa lain.

Dalam rangka upaya mewujudkan pengajaran yang mendidik, perlu pula dikemukakan bahwa setiap keputusan dan tindakan dari dosen dalam rangka kegiatan belajar mengajar akan membawa dampak atau efek kepada mahasiswa. Untuk mengantisipasi itu semua peranan dosen sangatlah penting artinya dalam pencapaian hasil yang diharapkan. dosen yang baik bukan sekedar mampu dalam penyampaian informasi penting kepada peserta didiknya namun juga dapat menumbuhkan motivasi belajar mahasiswa.

Dalam proses belajar mengajar terdapat banyak faktor yang mempengaruhi kemampuan belajar ilmu alamiah. Faktor-faktor tersebut dapat dikelompokkan menjadi dua, yaitu faktor internal dan faktor eksternal. Beberapa faktor eksternal yang ikut berperan dalam peningkatan kemampuan belajar ilmu alamiah adalah faktor keluarga, lingkungan, dosen, metode pembelajaran, fasilitas studi, teman pergaulan, intensitas waktu belajar dan lain sebagainya. Sedangkan faktor internal yang ikut berperan dalam meningkatkan kemampuan belajar ilmu alamiah adalah motivasi, gaya belajar, cita-cita, sikap terhadap guru mata pelajaran, dan sebagainya.

Dari uraian yang dikemukakan di atas peneliti lebih memilih menganalisis gaya belajar dan motivasi belajar sebagai bagian yang memberikan dampak paling signifikan dalam peningkatan kemampuan belajar ilmu alamiah dasar.

\section{TINJAUAN PUSTAKA}

\section{Gaya Belajar}

Setiap individu adalah unik. Artinya setiap individu memiliki perbedaan antara yang satu dengan yang lain. Perbedaan tersebut bermacam-macam, mulai dari perbedaan fisik, pola berpikir dan cara-cara merespon atau mempelajari hal-hal baru. Dalam hal belajar, masing-masing anak memiliki kelebihan dan kekurangan dalam menyerap pelajaran yang diberikan, sehingga kita tidak bisa memakskan seorang anak harus belajar dengan suasana dan cara yang kita inginkan karena masing-masing anak mempunyai tpe atau gaya belajar sendiri-sendiri. Kemampuan anak dalam menangkap materi dan pelajaran tergantung dari gaya belajarnya. Gaya belajar dapat dikatakan sebagai cara khas yang digunakan seseorang dalam mengamati dan beraktivitas mental di bidang kognitif, yang bersifat individual dan kerapkali tidak disadari dan cenderung bertahan terus. 
Sejalan dengan definisi di atas, Nasution (2008: 37) mengemukakan bahwa "Gaya kognitif (gaya belajar) adalah cara yang konsisten yang dilakukan oleh seorang murid dalam menangkap stimulus atau informasi, cara mengingat, berpikir, dan memecahkan masalah." Gaya belajar merujuk pada cara orang memperoleh informasi dan menggunakan strategi untuk merespon suatu tugas. Disebut sebagai gaya dan tidak sebagai kemampuan karena merujuk pada bagaimana orang memproses informasi dan memecahkan masalah, dan bukan merujuk pada bagaimana cara yang terbaik dalam memproses informasi dan memecahkan masalah.

Mengenai jenis-jenis gaya kognitif, Winkel (2006) yaitu: "Membedakan dalam beberapa jenis berdasarkan kecenderungan, seperti: (a) cenderung bergantung pada medan (field dependent) atau cenderung tidak tergantung pada medan (field idepemdent), (b) Kecenderungan konsisten atau mudah meninggalkan cara yang telah dipilih dalam mempelajari sesuatu, (c) kecenderungan luas atau sempit dalam pembentukan konsep, dan (d) cenderung sangat atau kurang memperhatikan perbedaan antara objek-objek yang diamati." Sedangkan Ardana (2008) mengutip, Pembagian gaya kognitif (gaya belajar) yang dikemukakan oleh Siegel dan Coop (1974), yaitu: “(a) mengutamakan perhatian global versus perhatian detail (bagian), (b) membedakan suatu stimulus ke dalam kategori yang lebih besar versus kategori bagian-bagian kecil, (c) kecendrungan mengklasifikasi item berdasarkan karakteristik yang nampak seperti kesamaan fungsi, waktu, atau ruang versus memilih kesamaan dari beberapa atribut yang abstrak, (d) cepat (impulsive) versus lambat, sungguh-sungguh dalam pemecahan masalah (reflexsive), dan (e) Intuitif, induktif versus kognitif logik, kognitif deduktif."

Gaya belajar adalah suatu stimulus yang muncul dari kegiatan belajar yang digunakan dalam pemecahan masalah di kelas. Menurut Soemanto (1994: 120-121) menyatakan bahwa "tingkah laku kognitif merupakan tindakan mengenal atau memikirkan situasi di mana tingkah laku terjadi". Tingkah laku tergantung pada insight (pengamatan atau pemahaman) terhadap hubungan yang ada dalam situasi. Ada tiga gaya belajar yang dikemukakan oleh Nasution (2000: 93) "penelitian tentang gaya belajar pebelajar diadakan dalam tiga bidang yakni gaya kognitif pebelajar, gaya respon pebelajar terhadap stimulus dan model belajar". Salah satu gaya belajar yang telah dipelajari secara meluas adalah gaya belajar kognitif. Individu yang belajar dengan gaya field-independent cenderung menyatakan suatu gambaran lepas dari latar belakang gambaran tersebut, serta mampu membedakan objek-objek dari konteks sekitarnya dengan lebih mudah, memandang keadaan sekeliling lebih secara analitis dan umumnya mampu dengan mudah menghadapi tugas-tugas yang memerlukan perbedaan-perbedaan dan analisis. Umumnya pebelajar yang field-independent tidak dipengaruhi oleh lingkungan atau kurang dipengaruhi oleh lingkungan. Menurut Nurita Putranti (2009), di dalam buku Quantum Learning dipaparkan 3 modalitas belajar seseorang yaitu: "Modalitas visual, auditori atau kinestetik (V-A-K). Walaupun masing-masing dari kita belajar dengan menggunakan ketiga modalitas ini pada tahapan tertentu, kebanyakan orang lebih cenderung pada salah satu di antara ketiganya.

Modalitas belajar adalah cara informasi masuk ke dalam otak melalui indra yang kita miliki. Pada saat informasi tersebut akan ditangkap oleh indra, maka bagaimana informasi tersebut disampaikan (modalitas) berpengaruh pada kecepatan otak menangkap informasi dan kekuatan otak menyimpan informasi tersebut dala ingatan atau memori (Munif Chatib 2009). Pentingnya modalitas dalam belajar sangat menentukan gaya belajar seseorang dalam meningkatkan hasil belajar sehingga orang cenderung memiliki salah satu dari gaya belajarnya. Dalam penelitian ini dibedakan gaya belajar: 1) Gaya belajar visual, 2) Gaya belajar auditori, dan 3) Gaya belajar kinestetik. 


\section{Motivasi Belajar}

Motivasi merupakan perilaku yang ditujukan kepada sasaran, motivasi berkaitan dengan tingkat usaha yang dilakukan oleh seseorang dalam mengejar suatu tujuan yang berkaitan erat dengan kepuasan pekerja. Sedangkan pengertian motivasi menurut Sumadi Suryabrata adalah suatu keadaan yang terdapat dalam diri seseorang yang mendorongnya untuk melakukan aktivitas tertentu guna suatu pencapaian tujuan.

Menurut Purwanto (2007: 71) motivasi adalah "pendorongan"; suatu usaha yang disadari untuk mempengaruhi tingkah laku seseorang agar tergerak hatinya untuk bertindak melakukan sesuatu sehingga mencapai hasil atau tujuan tertentu. Jadi motivasi timbul akibat dorongan yang terjadi dalam diri individu baik secara alimiah maupun paksaan. Seorang anak yang ingin mendapat prestasi di sekolah karena keinginan dalam diri sendiri dapat disebut sebagai motivasi alamiah, sedangkan seorang siswa yang ingin berprestasi karena ingin mengungguli teman-temannya dapat dikategorikan motivasi karena paksaan. Menurut Sardiman (2009: 75) motivasi dapat juga diartikan sebagai usaha untuk menyediakan kondisi-kondisi tertentu, sehingga seseorang mau dan ingin melakukan sesuatu dan apabila tidak suka ia akan berusaha meniadakan perasaan tidak suka itu.

Menurut Yamin (2007: 217) motivasi berhubungan dengan: 1) arah perilaku, 2) kekuatan respon (yakni usaha) setelah belajar siswa memilih mengikuti tindakkan tertentu, dan 3) ketahanan prilaku, atau beberapa lama seseorang itu terus menerus berprilaku menurut cara tertentu.

Motivasi belajar merupakan daya penggerak psikis dari dalam diri seseorang umtuk dapat melakukan kegiatan belajar dan menambah keterampilan, pengalaman. Motivasi mendorong dan mengarah minat belajar untuk mencapai suatu tujuan. Siswa akan bersungguh-sungguh belajar karena termotivasi mencapai prestasi tertentu.

\section{a). Pertama}

Ada 6 konsep penting motivasi belajar menurut Setiawan (2003: 37):

Motivasi belajar adalah proses internal yang mengaktifkan, memandu dan mempertahankan perilaku dari waktu ke waktu. Individu termotivasi karena berbagai alasan yang berbeda, dengan intensitas yang berbeda. Sebagai misal, seorang siswa dapat tinggi motivasinya untuk menghadapi tes ilmu sosial dengantujuan mendapatkan nilai tinggi (motivasi ekstrinsik) dan tinggi motivasinya menghadapi tes IPA karena tertarik dengan mata pelajaran tersebut (motivasi intrinsik).

\section{b). Kedua}

Motivasi belajar bergantung pada teori yang menjelaskannya, dapat merupakan suatu konsekuensi dari penguatan (reinforcement), suatu ukuran kebutuhan manusia, suatu hasil dari disonan atau ketidakcocokan, suatu atribusi dari keberhasilan atau kegagalan, atau suatu harapan dari peluang keberhasilan.

\section{c). Ketiga}

Motivasi belajar dapat ditingkatkan dengan penekanan tujuan-tujuan belajar dan pemberdayaan atribusi.

\section{d). Keempat}

Motivasi belajar dapat meningkat apabila guru membangkitkan minat siswa, memelihara rasa ingin tahu mereka, menggunakan berbagai macam strategi pengajaran, menyatakan harapan dengan jelas, dan memberikan umpan balik (feed back) dengan sering dan segera.

\section{e). Kelima}

Motivasi belajar dapat meningkat pada diri siswa apabila guru memberikan ganjaran yang memiliki kontingen, spesifik, dan dapat dipercaya. 


\section{f). Keenam}

Motivasi berprestasi dapat didefinisikan sebagai kecendrungan umum untuk mengupayakan keberhasilan dan memilih kegiatan-kegiatan yang berorientasi pada keberhasilan/kegagalan. Siswa dapat termotivasi dengan orientasi ke arah tujuan-tujuan penampilan. Mereka mengambil mata pelajaran-mata pelajaran yang menantang. Siswa yang berjuang demi tujuan-tujuan penampilan berusaha untuk mendapatkan penilaian positip terhadap kompetensi mereka. Mereka berusaha untuk mendapat nilai baik dengan cara menghindar dari mata pelajaran yang sulit. Guru dapat membantu siswa dengan mengkomunikasikan bahwa keberhasilan itu mungkin dicapai. Guru dapat menunggu siswa menjawab pertanyaan-pertanyaan dan sejauh mungkin menghindari pembedaan prestasi di antara para siswa yang tidak perlu.

\section{Kemampuan Belajar Ilmu Alamiah Dasar}

Belajar menurut Dalyono (2005: 49) bahwa: "Belajar adalah suatu usaha. Perbuatan yang dilakukan secara sungguh-sungguh, dengan sistematis, mendayagunakan semua potensi yang dimiliki, baik fisik, mental serta dana, panca indra, otak dan anggota tubuh lainnya, demikian pula aspek kejiwaan seperti intelegensi, bakat, motivasi, minat dan sebagainya." Dalam hal ini, berarti belajar juga memerlukan bagian panca indera untuk merangsang intelegensi seseorang dalam melakukan dan memutuskan sesuatu. Pengalaman-pengalaman yang didapat seseorang dengan usaha dari berbagai ilmu dapat ditunjukkan dengan suatu perubahan tingkah laku maka akan menyebabkan pengalaman itu sendiri sebagai proses dari belajar.

Menurut Jasin (2012: 11) ilmu alamiah mempelajari segala sesuatu di alam semesta ini sehingga alam semesta menjadi objek. Tujuan ilmu alamiah adalah mencari kebenaran tentang objeknya dan kebenaran itu bersifat relatif. Alam semesta sebagai objek penyelidikan mempunyai aspek yang sangat luas misalnya aspek fisis, aspek kimiawi, aspek biologis, aspek ekonomis dan sebagainya. Untuk mencapai kebenaran, yakni pesesuaian antara pengetahuan dan objeknya tidaklah terjadi secara kebetulan tetapi harus menggunakan prosedur yang tepat dan tearah yaitu metode ilmiah. Ilmu alamiah lahir sebagai bagian dari fitrah manusia sebagai mahluk yang berakal. Sebagai mahluk yang berakal manusia diberikan rasa ingin tahu (kuroisitas) yang sangat tinggi dan dilengkapi pula dengan akal sebagai alat untuk memutuskan sesuatu persoalan. Filsafat ilmu alamiah meliputi: 1) Vitalisme, 2) Mekanisme, 3) Agnotisme, dan 4) Filsafat Pancasila.

Kemampuan belajar ilmu alamiah pada hakikatnya merupakan keberhasilan dalam mengubah cara pikir, tingkah laku dan analisa mahasiswa terhadap kebenaran yang terjadi disekitarnya terutama yang berkaitan dengan lingkungan hidup. Kemampuan ini lebih bersifat personal, oleh karenanya kemampuan belajai ilmu alam dapat terlihat dalam pola kehidupannya sehari-hari.

\section{METODE}

Berdasarkan tujuan dan perumusan masalah penelitian di atas, maka jenis penelitian yang akan digunakan dalam penelitian ini adalah dengan menggunakan metode survey Expose Facto. Data diperoleh dari skor kemampuan belajar ilmu alamiah dasar yang dilihat dari gaya belajar mahasiswa dan motivasi belajar mahasiswa.

Dalam penelitian ini terdapat dua variable yaitu gaya belajar dan motivasi belajar sebagai variable bebas dan kemampuan belajar ilmu alamiah dasar sebagai variabel terikat. Adapun metode yang akan digunakan dalam penelitian ini adalah metode penelitian survey dengan desain factorial $2 \times 3$. 
Populasi dalam penelitian ini adalah seluruh mahasiswa reguler yang mengikuti perkuliah ilmu alamiah dasar tahun akademik 2014/2015. Adapun jumlah populasi 335 mahasiswa. Sampel dalam penelitian ini berjumlah 25\% dari total populasi (Arikunto, 112: 2002), sehingga Jumlah mahasiswa yang dijadikan sampel sebesar 84 orang.

Penulis mengambil tiga jenis data dalam penelitian ini. Ketiga data tersebut terbentuk skor yang diperoleh dari: data non tes (gaya belajar dan motivasi belajar) dan data tes (kemampuan belajar ilmu alamiah dasar). Data gaya belajar siswa dan motivasi belajar siswa dikumpulkan dengan instrumen yang berbentuk skala sikap dan data kemampuan belajar ilmu alamiah dasar berupa ulangan akhir semester (UAS) yang mencakup mata pelajaran ilmu alamiah dasar. Instrumen diberikan langsung kepada subjek yang akan memberikan jawaban dengan memilih salah satu jawaban yang sudah tersedia untuk skala sikap dan tes tulis essay untuk data kemampuan belajar ilmu alamiah dasar.

Teknik analisis data dalam penelitian ini meliputi uji persyaratan analisis data dan uji hipotesis penelitian. Uji persyaratan analisis data meliputi:

1. Uji normalitas dengan chi kuadrat

2. Uji homogenitas dengan uji bartllet

Sedangkan uji hipotesis penelitian menggunakan uji anova dua arah dengan desain faktorial 2 x 3 .

\begin{tabular}{|c|c|c|c|c|}
\hline Variabel Penelitian & $\mathbf{A - 1}$ & $\mathbf{A - 2}$ & $\mathbf{A - 3}$ & $\boldsymbol{\Sigma} \mathbf{B}$ \\
\hline $\mathbf{B - 1}$ & $\mathrm{Y}_{11}$ & $\mathrm{Y}_{12}$ & $\mathrm{Y}_{13}$ & $\mathrm{Y}_{10}$ \\
\hline $\mathbf{B - 2}$ & $\mathrm{Y}_{21}$ & $\mathrm{Y}_{22}$ & $\mathrm{Y}_{23}$ & $\mathrm{Y}_{20}$ \\
\hline $\boldsymbol{\Sigma} \mathbf{A}$ & $\mathrm{Y}_{01}$ & $\mathrm{Y}_{02}$ & $\mathrm{Y}_{03}$ & $\mathrm{Y}_{00}$ \\
\hline
\end{tabular}

Keterangan:

$Y_{11}:$ Kemampuan belajar IAD dengan gaya belajar visual dan motivasi tinggi.

$\mathrm{Y}_{12}$ : Kemampuan belajar IAD dengan gaya belajar auditori dan motivasi tinggi.

$\mathrm{Y}_{13}:$ Kemampuan belajar IAD dengan gaya belajar kinestetik dan motivasi tinggi.

$\mathrm{Y}_{21}$ : Kemampuan belajar IAD dengan gaya belajar visual dan motivasi rendah.

$\mathrm{Y}_{22}$ : Kemampuan belajar IAD dengan gaya belajar auditori dan motivasi rendah.

$\mathrm{Y}_{23}$ : Kemampuan belajar IAD dengan gaya belajar kinestetik dan motivasi rendah.

\section{HASIL DAN PEMBAHASAN}

\section{Hasil Penelitian}

Tabel 1. Hasil Perhitungan Statistik Deskriptif

\begin{tabular}{|c|c|c|c|c|}
\hline \multirow{2}{*}{ (B) } & \multicolumn{3}{|c|}{ Gaya Belajar (A) } & \multirow{2}{*}{ Jumlah } \\
\cline { 2 - 5 } & $\mathrm{A} 1$ & $\mathrm{~A} 2$ & $\mathrm{~A} 3$ & \\
\hline \multirow{4}{*}{ B1 } & $\mathrm{n}=14$ & $\mathrm{n}=14$ & $\mathrm{n}=14$ & $\mathrm{n}=42$ \\
\cline { 2 - 5 } & $\mathrm{X}=21$, & $\mathrm{X}=18,64$ & $\mathrm{X}=14,85$ & $\mathrm{X}=18,16$ \\
\cline { 2 - 5 } & $\mathrm{S}=1,79$ & $\mathrm{~s}=2,87$ & $\mathrm{~s}=3,15$ & $\mathrm{~s}=2,60$ \\
\hline \multirow{4}{*}{ B2 } & $\mathrm{n}=14$ & $\mathrm{n}=14$ & $\mathrm{n}=14$ & $\mathrm{n}=42$ \\
\cline { 2 - 5 } & $\mathrm{X}=19,71$ & $\mathrm{X}=19,57$ & $\mathrm{X}=19,14$ & $\mathrm{X}=19,47$ \\
\cline { 2 - 5 } & $\mathrm{s}=2,46$ & $\mathrm{~s}=2,79$ & $\mathrm{~s}=3,57$ & $\mathrm{~s}=2,94$ \\
\hline \multirow{4}{*}{$\sum$} & $\mathrm{n}=28$ & $\mathrm{n}=28$ & $\mathrm{n}=28$ & $\mathrm{n}=84$ \\
\cline { 2 - 5 } & $\mathrm{X}=20,35$ & $\mathrm{X}=19,10$ & $\mathrm{X}=16,99$ & $\mathrm{X}=18,81$ \\
\hline & $\mathrm{s}=2,12$ & $\mathrm{~s}=2,83$ & $\mathrm{~s}=3,36$ & $\mathrm{~s}=2,77$ \\
\hline
\end{tabular}


Dari data pada tabel 1, dapat dilihat bahwa rata-rata gaya belajar visual 20,35 ; gaya belajar auditori 19,10 dan gaya belajar kinestetik 18,81. Sedangkan motivasi belajar tinggi memiliki rata-rata 18,16 dan motivasi belajar rendah 19,47.

\section{Uji Normalitas Data}

\section{a. Uji normalitas data gaya belajar}

Dari hasil pengujian didapat sig Gaya Belajar visual $\left(\mathrm{A}_{1}\right)=0,552>0,05$; sig Gaya Belajar auditori $\left(\mathrm{A}_{2}\right)=0,705>0,05$; sig Gaya Belajar kinestetik $\left(\mathrm{A}_{3}\right)=0,617>$ 0,05 . Karena semua data lebih besar dari 0,05 maka semua data dinyatakan normal atau berasal dari populasi berdistribusi normal.

\section{b. Uji normalitas data motivasi belajar}

Dari hasil pengujian didapat sig Minat Belajar tinggi $\left(B_{1}\right)=0,223>0,05$ dan sig Minat Belajar rendah $\left(\mathrm{B}_{2}\right)=0,557>0,05$. Dengan demikian dapat disimpulkan bahwa data berasal dari populasi berdistribusi normal.

\section{Uji Homogenitas}

Dari hasil pengujian dengan SPSS 16 diperoleh nilai sig 0,098>0,05 dengan demikian Ho diterima dan $\mathrm{H}_{1}$ ditolak dan data berasal dari populasi yang homogen. Dari hasil pengujian normalitas dan homogenitas dapat disimpulkan bahwa persyaratan yang harus dipenuhi dalam penelitian ini telah terpenuhi, maka dapat dilanjutkan dengan uji hipotesis penelitian.

\section{Pengujian Hipotesis Penelitian}

Tabel 2. Hasil Pengujian Hipotesis

\begin{tabular}{|c|c|c|c|c|c|}
\hline \multicolumn{7}{|c|}{ Tests of Between-Subjects Effects } & \\
\hline Dependent Variable: Kemampuan Belajar IAD & Sig. \\
\hline Source & $\begin{array}{c}\text { Type III Sum of } \\
\text { Squares }\end{array}$ & df & $\begin{array}{c}\text { Mean } \\
\text { Square }\end{array}$ & F & 0,00 \\
\hline Corrected Model & 307,39 & 5 & 61,479 & 7,673 & 0,00 \\
\hline Intercept & 29756,6 & 1 & 29756,6 & 3,7143 & 0,00 \\
\hline GB & 161,21 & 2 & 80,607 & 10,061 & 0,037 \\
\hline Motivasi & 36,012 & 1 & 36,012 & 4,495 & 0,002 \\
\hline GB * Motivasi & 110,16 & 2 & 55,083 & 6,875 & \\
\hline Error & 624,92 & 78 & 8,012 & & \\
\hline Total & 30689 & 84 & & & \\
\hline Corrected Total & 932,321 & 83 & & & \\
\hline a. R Squared $=.330$ (Adjusted R Squared =.287) & & \\
\hline
\end{tabular}

\section{Pengujian Hipotesis 1:}

Terdapat pengaruh gaya belajar terhadap kemampuan belajar ilmu alamiah dasar. Hipotesis diuji dengan melihat koefisien signifikan.

- Jika nilai sig $>0,05$; maka Ho diterima dan $\mathrm{H}_{1}$ ditolak

- Jika nilai sig < 0,05; maka $\mathrm{H}_{1}$ diterima dan Ho ditolak

Dari pengujian dengan spss 16 diatas didapat sig untuk gaya belajar $0,00<0,05$ dengan demikian dapat disimpulkan terdapat pengaruh gaya belajar terhadap kemampuan belajar ilmu alamiah dasar. Dan rata-rata kemampuan belajar ilmu alamiah dasar yang 
belajar dengan gaya belajar visual $(20,35)$ lebih tinggi daripada siswa yang belajar dengan gaya belajar auditori $(19,10)$ dan gaya belajar kinestetik $(17,0)$.

\section{Pengujian Hipotesis 2:}

Terdapat pengaruh Motivasi Belajar terhadap kemampuan belajar ilmu alamiah dasar. Hipotesis diuji dengan melihat koefisien signifikan. Dari pengujian dengan spss 16 diatas didapat Terdapat pengaruh motivasi belajar terhadap kemampuan belajar ilmu alamiah dasar. Hal ini ditandai dengan nilai sig untuk kemandirian 0,037 < 0,05 dengan demikian dapat disimpulkan terdapat pengaruh motivasi belajar terhadap kemampuan belajar ilmu alamiah dasar. Dan rata-rata kemampuan belajar ilmu alamiah dasar yang memilki motivas belajar tinggi $(18,16)$ lebih kecil daripada kemampuan belajar ilmu alamiah dasar yang memiliki motivasi belajar rendah $(19,47)$.

\section{Pengujian Hipotesis 3:}

Terdapat pengaruh interaksi gaya belajar dan motivasi belajar terhadap kemampuan belajar ilmu alamiah. Hipotesis diuji dengan melihat koefisien signifikan. Dari pengujian dengan spss $16 \mathrm{di}$ atas didapat sig untuk model gaya belajar dan motivasi belajar 0,002 < 0,05 dengan demikian dapat disimpulkan terdapat pengaruh interaksi gaya belajar siswa dan motivasi belajar terhadap kemampuan belajar ilmu alamiah dasar.

\section{PENUTUP}

Berdasarkan analisis data di atas maka dapat disimpulkan Terdapat pengaruh gaya belajar siswa terhadap kemampuan belajar ilmu alamiah dasar. Dari pengujian dengan spss 16 diatas didapat sig untuk gaya belajar $0,00<0,05$ dengan demikian dapat disimpulkan terdapat pengaruh gaya belajar terhadap kemampuan belajar ilmu alamiah dasar.

Terdapat pengaruh motivasi belajar siswa terhadap kemampuan belajar ilmu alamiah dasar. Dari pengujian dengan spss 16 diatas didapat Terdapat pengaruh motivasi belajar terhadap kemampuan belajar ilmu alamiah dasar. Hal ini ditandai dengan nilai sig untuk kemandirian 0,037 $<0,05$ dengan demikian dapat disimpulkan terdapat pengaruh motivasi belajar terhadap kemampuan belajar ilmu alamiah dasar.

Terdapat pengaruh interaksi gaya belajar dan minat belajar siswa terhadap kemampuan belajar ilmu alamiah. Hal ini diandai dengan nilai sig interaksi gaya dan motivasi belajar siswa $0,002<0,05$ dan didukung dengan perolehan nilai $\mathrm{F}$ hitung diamana $\mathrm{F}_{\text {hitung }} 6,87>\mathrm{F}_{\text {tabel }}$ 3,96. Dengan demikian $\mathrm{H}_{1}$ diterima dan $\mathrm{H}_{0}$ ditolak sehingga disimpulkan terdapat pengaruh interaksi gaya belajar dan motivasi belajar terhadap kemampuan belajar ilmu alamiah.

\section{DAFTAR PUSTAKA}

Ardana, Suhendar. 2008. Menakar Gaya Belajar Peserta Didik. Bandung: Tarsito Arikunto, Suharsimi. 2002. Prosedur Penelitian. Jakarta: Rineka Cipta. Jasin, Maskoeri. 2012. Ilmu Alamiah Dasar. Jakarta: PT. Raja Grafindo Persada M, Dalyono. 2005. Psikologi Pendidikan. Jakarta: Rineka Cipta Nasution. 2008. Didaktik Asas-asas Mengajar. Bandung: Jemmars.

Purwanto M, Ngalim. 2007. Psikologi Pendidikan. Bandung: Remaja Rosdakarya

Riduwan. 2008. Analisis Metode Pembelajaran. Bandung: Alfabeta.

Sardiman. 2009. Interaksi dan Motivasi Belajar Mengajar. Jakarta: Grafindo.

Setiawan, Ahmad.2003. Kiat-Kiat Menumbuhkan Motivasi Belajar Anak. PT. Bandung: Remaja Rosdakarya.

Winkel. 2006. Psikologi Pendidikan dan Evaluasi Pendidikan. Jakarta: Gramedia 